\title{
Конференции
}

ГАМАН-ГОЛУТВИНА Оксана Викторовна - доктор политических наук, член-корреспондент РАН, профессор; заведующий кафедрой сравнительной политологии Московского государственного института межжународных отношений (университет) МИД РФ (119454, Россия, г. Москва, nр-кт Вернадского, 76, корп. B; ogaman@таil.ru)

СМОРГУНОВ Леонид Владимирович - доктор философских наук, профессор; заведующий кафедрой политического управления Санкт-Петербургского государственного университета (191124, Россия, г. Санкт-Петербург, ул. Смольного, 1/3, под. 7; l.morgunоv@spbu.ru)

ТИМОФЕЕВА Лидия Николаевна - доктор политических наук, профессор; научный руководитель Школы политических исследований Института общественных наук Российской академии народного хозяйства и государственной службы при Президенте РФ (119606, Россия, г. Москва, nр-кт Вернадского, 84; timofeeva-lidiya@inbox.ru)

\section{ТРАЕКТОРИИ ПОЛИТИЧЕСКОГО РАЗВИТИЯ РОССИИ}

\begin{abstract}
Аннотация. В статье речь идет об основных вопросах, рассмотренных на всероссийской конференции с международным участием «Траектории политического развития России: институты, проекты, акторы», организованной Российской ассоциацией политической науки, которая прошла 6-7 декабря 2009 г. в Москве, в МПГУ. В ней приняли участие около 500 политологов, представляющих университеты и исследовательские центры из 50 регионов России и более 10 стран мира. Главной задачей конференции стало определение траекторий политического развития России, поиск новой повестки дня для страны и ее будущее как объект политологического исследования. Конференция отразила кризисное состояние современной политической науки, определенные разрывы в представлении о внутриполитической повестке дня, общий запрос на политическое ответственное развитие, потребность справедливости, сложность политической идентификации и открытое представление о политическом будущем в контексте сложного и неопределенного мира.
\end{abstract}

Ключевые слова: политическое развитие, траектории политического развития, постнеклассическая наука, методология и методика политической науки, новый политический язык, внутриполитическая повестка дня, формирование политической идентичности, политическое будущее

Граектории политического развития России: институты, проекты, акторы» - такой была тема ежегодной всероссийской научной конференции с международным участием, которая состоялась 6-7 декабря 2019 г. в Москве, в МПГУ. Ее организатор, Российская ассоциация политической науки, - старейшая организация политологов, которой в 2020 г. исполняется 65 лет. В ней приняли участие около 500 политологов, представляющих университеты и исследовательские центры из 50 регионов России и более 10 стран мира (Китай, Италия, Испания, Болгария, Польша, Словения, Армения, Казахстан, Узбекистан, Украина и др.). Главной задачей конференции стало определение траекторий политического развития России, поиск новой повестки дня для страны и ее будущее как объект политологического исследования.

Конференция прошла в условиях ряда заметных трансформаций в области реальной политики и изменений в политической науке. Во внутренней политике усиливается запрос на интенсификацию изменений, которые позволили бы стране выйти в пространство явного экономического роста за счет внедрения достижений науки и техники, отражающих тенденции четвертой промышленной революции. Общим знаком изменений становится цифровизация государственного управления, всего процесса общественно-государственного взаимодействия. В международной политике отмечаются многообразные усилия диверсифицировать направления деятельности на установление разно- 
образных отношений по весьма широкому спектру межстранового и международного регионального сотрудничества. Санкционные войны демонстрируют свою неэффективность, а стремление к однополярному доминированию наталкивается на сопротивление. Растет число международных сетей и объединений, целью которых становится достижение устойчивого, сбалансированного и инклюзивного развития. В этом отношении повышается спрос на определение различных траекторий развития, которые в сумме позволили бы странам решать перспективные задачи, опираясь на свои конкурентные преимущества и эффективные международные альянсы.

Изменения в политической науке не так заметны, однако и здесь идет поиск новых методологий, теорий и направлений. Отметим 3 проявляющихся процесса. Во-первых, налицо эффект давно обсуждаемого движения за междисциплинарную интеграцию научного знания. В изучении политики оно выявилось как стремление к пересечению границ в объектной, предметной, методологической и методической частях исследований (количественные и качественные, мягкие и строгие методы, изучение природы и общества, сети и ассамбляжи, законы и неопределенность и т.д.). Во-вторых, политическая наука испытывает дефицит больших теорий, «великих метанарративов», подвергнутых в свое время деконструкции со стороны постмодернизма. Споры о либерализме, консерватизме, либертарианстве, коммунизме демонстрируют ограниченность прежних духовных конструктов, а их использование ведет к радикализации политического процесса. Новые же метанаррации пока не заявляют о себе, что может быть свидетельством того, что мы живем в то время, которое лишь является своеобразной подготовкой к новым великим концептуализациям, которые уже не будут носить на себе отпечаток «центризма». В-третьих, проблематизируется роль самого научного знания, его места и роли в трансформационных процессах. Появление «гражданской науки», построенной на основе доступности больших данных для всех, является лишь одним из сигналов этой проблематизации. Знание в широком смысле является фактором развития, что расширяет пространство его производства и использования. Наука, если можно так сказать, становится общественным производством.

Все эти и другие соображения были положены в основание проведения настоящей конференции. Цель конференции - рассмотреть различные аспекты траекторий политического развития России; особое внимание уделить вопросам проектирования, деятельности политических институтов и акторов, обеспечивающих перевод политических требований в изменения в политическую повестку дня и политические решения.

Пленарное заседание прошло 6 декабря в именной аудитории МПГУ, посвященной А.Ф. Лосеву. С приветственным словом к собравшимся обратился ректор МПГУ $\boldsymbol{A . B}$. Лубков, который отметил значение конференции как всероссийского научного мероприятия и высказал пожелание ее успешной работы.

С вступительным словом «Современная политическая наука: актуальные измерения и вызовы» выступила президент РАПН, член-корреспондент РАН, профессор, заведующий кафедрой сравнительной политологии О.В. ГаманГолутвина (МГИМО МИД РФ). В связи с неединичными оценками состояния современной политической науки как кризисного докладчик остановилась на анализе политической компаративистики, включая ее методологические измерения и методический инструментарий. В докладе эволюция компаративистики раскрывалась как переход от методологической полифонии конца XX - начала XXI в. к мультипарадигмальному плюрализму. Нынешнее состояние компаративистики, как показал докладчик, не рассматривается как кризисное, но оценивается как нуждающееся в существенном обновлении. В докладе 
О.В. Гаман-Голутвина предлагает рассматривать его скорее как фазу «нормальной науки» в терминах Т. Куна. Ключевой проблемой представляется нахождение методологического алгоритма компаративистики, адекватного постнеклассической динамике политики. Рассмотрение используемых в настоящее время сравнительных методов показывает, что ключевая задача в этой сфере - уточнение эффективного алгоритма использования количественных методов в связи с получившими распространение упрощенными процедурами их применения. Это определяет востребованность «компаративной» версии «Великих дебатов» для структурирования предметного поля, обновления методологии и методов субдисциплины.

Доклад профессора кафедры менеджмента P.B. Eвстифеева (РАНХиГС при Президенте РФ, Владимирский филиал) «Тенденции формирования нового политического языка в условиях глобальных информационных вызовов» раскрывает особенности политического языка, характеризующего современную публичную сферу, и его отражение в языке политической науки. Как было показано в докладе, развитие глобальных процессов диктует необходимость более точной и тонкой концептуализации политического языка, языковых практик и коммуникативных компетенций на национальном уровне, учитывающей развитие мировых языков и многоязычия, включая оценку перспектив гегемонии отдельных языков, переоценку разновидностей языков коренных народов и многоязычия, значимость которых ограничивается условиями языковых рынков. Такие исследовательские стратегии будут востребованы не только на национальном уровне, но и в мире современной глобализации, который является довольно условным и противоречивым, порождая как конфликты, так и сотрудничество.

В докладе члена-корреспондента РАН, профессора, заместителя директора ИМЭМО РАН И.С. Семененко «Политика развития: в поисках ИМЭМО им. Е.М. Примакова РАН новой повестки дня» был сделан акцент на ответственном развитии вопроса современной политической повестки дня. В докладе утверждалось, что принятие и реализация конкретных управленческих решений на уровне сообществ требует прочного политико-институционального обеспечения. Сама ценность гражданской самоорганизации становится императивом ответственного развития в контексте внедрения моделей эффективного управления.

Заведующий кафедрой социологии и политологии Воронежского государственного университета профессор $\boldsymbol{A}$. B. Глухова посвятила свой доклад теме «Внутриполитическая повестка дня как фактор единства современной России». В нем утверждается, что условием стабильности современного государства, подвергающегося воздействию многочисленных внутренних и внешних вызовов, становится его внутреннее единство, обусловленное солидарно понимаемыми целями и задачами его членов. В общественно-политическом сообществе сложилось солидарное мнение о том, что у России сегодня чрезвычайно сложная повестка с большим набором проблем. Докладчик выделяет три основных подхода к российской повестке: институциональную (правительственную) повестку, изложенную в официальных документах, выступлениях и заявлениях президента РФ и других официальных лиц; гражданскую повестку, продвигаемую преимущественно несистемной оппозицией, сохраняющей (в отличие от парламентских партий) свои независимые позиции в политическом поле; общественную («народную») повестку, отражающую запросы на решение наиболее острых проблем, волнующих большинство населения России.

С докладом «Роль мифологизированных и научных интерпретаций истории в формировании политической идентичности» выступил заведующий кафедрой 
всеобщей истории и международных отношений профессор Н.Г. Чернышов (Алтайский государственный университет). В нем утверждается, что различные варианты «политики памяти» и те интерпретации исторических событий, которые распространены в разных странах, тесным образом связаны с формированием политических идентичностей. При этом официальные интерпретации истории зачастую несут в себе мифологизированную идеологическую нагрузку. В докладе был сделан вывод, что в процессе формирования политической идентичности оптимальным является использование такой модели «политики памяти», при которой «реальная» и «мифологизированная» история не противоборствуют, а взаимно дополняют друг друга.

Заведующий кафедрой политологии Тверского государственного университета профессор $\boldsymbol{H . H}$. Козлова сделала доклад на тему «Траектории развития общественных палат в современной России». Докладчик представляет результаты анализа динамики развития общественных палат в регионах России как института гражданского общества. Она обратила внимание на расширение функционала общественных платформ, направления, инструменты их публичного влияния, а также совокупность инициатив, рекомендаций, мероприятий, проводимых общественными палатами и направленных на экономическое развитие региона, а также на различное наполнение их деятельности в условиях дифференциации отношений с органами государственной власти регионов.

Профессор кафедры политологии РГПУ им. А.И. Герцена T.Б. Рябова посвятила доклад теме «“Они же дети”? Символ детства в политической мобилизации современной России». Символ детства, как утверждает докладчик, будучи одним из наиболее эмоционально насыщенных, связанным с мифом и апеллирующим к личному опыту каждого индивида, давно находится в арсенале политической пропаганды. В докладе раскрывается ряд значений символа детства, которые являются достаточно устойчивыми, по крайней мере для современной эпохи. Символическая инфантилизация, как было показано, осуществляется на двух уровнях: первый - это прямая маркировка как ребенка, сравнение поведения политического актора с детским; второй предполагает наделение качествами, которые воспринимаются как атрибуты ребенка. В докладе анализировались различные практики использования этого символа в политической мобилизации.

Заведующий кафедрой политологии МПГУ профессор T.B. Kaрадже представила доклад «Будущее как объект политологического анализа». Речь в докладе идет о различных типах систем. Задача сложных открытых социополитических систем заключается не только в том, чтобы учитывать внешние детерминанты и, реагируя, корректировать и согласовывать их с внутренними процессами, но и в том, чтобы, выстраивая собственные адаптивные механизмы, повышать свою устойчивость и формировать детерминанты, определяющие развитие и трансформацию внешнего пространства. Будущее определяется типом динамичных закономерностей и потенциальными структурами сложных систем.

Заседания других форматов конференции прошли 6 и 7 декабря. Всего в ходе конференции были организованы 94 заседания по четырем типам форматов: заседания по основной теме конференции; заседания исследовательских комитетов; заседания круглых столов; презентационные заседания.

Заседания по основной теме конференции были посвящены вопросам истории трансформаций политического режима в современной истории России, исторической памяти и ее выражения в политических институтах, Конституции РФ и границам институциональной динамики, политическому развитию России и экономическому росту, проектам развития России, социальному неравенству и политике его ограничения, традициям российского 
государства и современному его развитию, политическим институтам современной России: президентству, Государственной думе, Совету Федерации, правительству, политическим партиям. Особое внимание было уделено агрегации интересов и политике разнообразия в гражданском обществе, этнополитической структуре России, политической стабильности и институциональному развитию, политическим вызовам и рискам четвертой промышленной революции, взаимодействию государства, бизнеса и гражданского общества, публичной политике и политическим трансформациям. Рассматривались также вопросы развития политических систем, соотношения внутренней и внешней политики.

Заседания по направлениям работы исследовательских комитетов РАПН проходили по тематике, определенной исследовательскими комитетами. В РАПН на сегодня действуют 22 исследовательских комитета, которые провели от 1 до 3 заседаний в зависимости от проявленного участниками интереса к теме.

Заседания круглых столов включали в себя разнообразные темы внутренней и внешней политики. Круглые столы были посвящены проблемам международных санкций и политическому развитию; гражданскому участию и политическому развитию России; возможностям развития молодежных сетевых сообществ и общественным институтам; конфликтам в городском пространстве; теории и практике делиберативной демократии; концептуальным основаниям, технологиям и перспективам государственной политики в сфере формирования идентичности; проблемам развития политической науки в России; проблемам политической регионалистики; вопросам социальной науки в эпоху четвертой промышленной революции - от возможностей цифровизации к трансформации профессиональной подготовки исследователей; молодежи в российском политическом процессе; советскому прошлому в настоящем; цифровизации публичного управления и гражданскому участию. Была проведена презентация результатов исследования по проектам, поддержанным президентом РФ, РНФ и РФФИ.

В рамках конференции прошло тематическое заседание Академии политической науки и отчетно-выборное собрание Академии. Президентом Академии политической науки на очередной срок избран доктор политических наук, профессор МГУ им. М.В. Ломоносова О.Ф. Шабров. Избран состав президиума Академии. Состоялись заседания секций Федерального учебно-методического объединения по группе направлений 41.00.00 - Политические науки и регионоведение, а также Совета молодых политологов РАПН.

6 декабря 2019 г. состоялась очередная отчетно-выборная конференция Российской ассоциации политической науки, в рамках которой был избран новый состав руководящих органов организации. 92 делегата заслушали и одобрили отчет о работе РАПН, его руководящих и рабочих органов. Затем прошли выборы нового состава руководящих органов РАПН. Президентом РАПН четвертый раз подряд избрана О.В. Гаман-Голутвина - член-корреспондент РАН, д.полит.н., профессор, заведующий кафедрой сравнительной политологии МГИМО МИД России, профессор-исследователь НИУ ВШЭ, председатель ФУМО «Политические науки и регионоведение», член Общественной палаты РФ, заместитель председателя Общественного совета при Минобрнауки РФ, председатель Экспертного совета РФФИ. Избрано правление РАПН. Председателем правления РАПН также вновь избрана Л.Н. Тимофеева, д.полит.н., профессор, научный руководитель Школы политических исследований ИОН РАНХиГС при Президенте РФ, вице-президент Академии политической науки. На новый 3-летний срок председателем научного совета РАПН переизбран Л.В. Сморгунов, д.филос.н., профессор, заведующий кафедрой 
политического управления факультета политологии Санкт-Петербургского государственного университета, вице-президент РАПН. В ходе отчетно-выборного собрания состоялось награждение дипломами победителей конкурса научных работ РАПН 2019 г.

Два дня работы ежегодной научной конференции РАПН отразили кризисное состояние современной политической науки, определенные разрывы в представлении о внутриполитической повестке дня, общий запрос на политическое ответственное развитие, потребность справедливости, сложность политической идентификации, плюрализм идей о формирующемся мировом порядке, значимость «политики памяти» и открытое представление о политическом будущем в контексте сложного и неопределенного мира.

GAMAN-GOLUTVINA Oksana Viktorovna, Dr.Sci. (Pol.Sci.), Corresponding Member of the RAS, Professor; Head of the Chair of Comparative Political Science, Moscow State Institute of International Relations (University) of the Ministry of Foreign Affairs of the Russian Federation (76 Vernadskogo Ave, Moscow, Russia, 119454; ogaman@mail.ru)

SMORGUNOV Leonid Vladimirovich, Dr.Sci. (Philos.), Professor; Head of the Chair of Political Governance, St. Petersburg State University (1/3 Smol'nogo St, St. Petersburg, Russia, 7191124; l.morgunov@spbu.ru)

TIMOFEeVA Lidia Nikolaevna, Dr.Sci. (Pol.Sci.), Professor; Academic Supervisor of the School of Political Studies, Institute of Social Sciences, Russian Presidential Academy of National Economy and Public Administration (RANEPA) (84 Vernadskjgo Ave, Moscow, Russia, 119606; Timofeeva-lidiya @inbox.ru)

\title{
THE TRAJECTORIES OF POLITICAL DEVELOPMENT OF RUSSIA
}

\begin{abstract}
The article deals with the main content of the All-Russian Conference "The Trajectories of Political Development: Institutions, Projects, Actors» with international participation, organized by the Russian Political Science Association, which was held on December 6-7, 2009 in Moscow, at Moscow State Pedagogical University. About 500 political scientists representing universities and research centers from 50 regions of Russia and more than 10 countries of the world took part in it. The main objective of the conference was to determine the paths of political development of Russia, to search a new agenda for the country and its future as an object of political science research. The conference reflected the crisis state of modern political science, certain gaps in the idea of an internal political agenda, a general request for political responsible development, the need for justice, the complexity of political identification and an open idea of the political future in the context of a complex and uncertain world.
\end{abstract}

Keywords: political development, trajectories of political development, post-non-classical science, methodology and methods of political science, new political language, domestic political agenda, formation of political identity, political future 